\author{
MiCHAє ŻEMŁA \\ Pedagogical University of Krakow, Poland \\ DARIA ELŻBIETA JAREMEN \\ Wroclaw University of Economics and Business, Poland \\ ELżBIETA NAWROCKA \\ Wroclaw University of Economics and Business, Poland
}

\title{
Consequences of development of the sharing economy in tourism for cities - theory and examples
}

\begin{abstract}
The purpose of the article is to identify the impacts generated in the cities by the sharing economy in tourism and the presentation of solutions appearing due to sharing economy development and implementation in particular cities. Contemporary cities are functioning in extremely dynamic conditions that are difficult to predict. In view of the globalising economy, progressive urbanisation, rapid changes in information and communication technologies, as well as social demographic, geopolitical and economic changes, new problems appear and solutions to them have to be implemented by cities. One of these phenomena that are relatively new and fast growing, and influence development of cities, is sharing economy (SE) in tourism. The greatest concern of the city authorities is fast and unrestrained development of services through global platforms in the accommodation and passenger transport industry, and the powerful global leaders of these markets - Airbnb and Uber have become very important partners for local governments, but also difficult ones. On the bases of extended literature review embracing scientific sources and industry reports it can be visible, that actions taken by the local authorities tend to be reactive not systematic and concentrated only on solving isolated current problems. It is postulated though that development of SE should be perceived in a way described by Hall (1994) as a third-order change. Several suggestions for future scientific research are also presented.
\end{abstract}

Keywords: Airbnb; city development; sharing economy; sustainable development; tourism services; Uber

Received: 22 December 2020

Accepted: 27 January 2020

Suggested citation:

Żemła, M., Jaremen, D.E., Nawrocka, E., (2021). Consequences of development of the sharing economy in tourism for cities - theory and examples. Prace Komisji Geografii Przemysłu Polskiego Towarzystwa Geograficznego [Studies of the Industrial Geography Commission of the Polish Geographical Society], 35(1), 109-122, doi: 10.24917/20801653.351.8

\section{INTRODUCTION}

Contemporary cities are functioning in extremely dynamic conditions that are difficult to predict. In view of the globalising economy, progressive urbanisation, rapid changes in information and communication technologies, as well as social demographic, 
geopolitical and economic changes, new problems appear and solutions to them have to be implemented by cities. One of these phenomena that are relatively new and fast growing, and influence development of cities, is sharing economy (SE) in tourism. Among the most important trends that shape the contemporary tourism in cities which is not conspicuous in other tourism destinations are rapid development of the sharing economy in tourism and establishment of huge global companies like Uber, Airbnb, and Couchsurfing as platforms to offer tourism services for collaborative consumption (Varsanis et al., 2019). The issue of the sharing economy in tourism gains a lot of interest from the academia yet the scientific knowledge about the phenomenon is scattered, not grounded, and not following the pace of the development of the phenomenon (Jaremen, Nawrocka, Żemła, 2019). Development of SE in tourism services can be seen mainly in big, global cities, such as New York, Berlin, Barcelona or Paris. More and more research proves that this phenomenon significantly impacts city tourism by stimulating tourism traffic direction to cities, and also by creating a new dimension of competition in tourism business. However, as contemporary cities are complex and open systems which are shaped by numerous relations between their elements, external effects of sharing economy development go far beyond tourism business (Moreno-Izquierdo et al., 2019). Local authorities in particular cities try to estimate both the benefits and costs that are brought by the multilayered phenomena of SE and adopt differentiated approaches and tools as their respond. The aim of the paper is to determine the most commonly utilized tools and approaches taken by cities' authorities worldwide. The method used in the research is critical literature review. The aim was achieved through description and synthesis of actions implemented in different cities which were already presented in the literature. There are numerous case studies and industry reports that present the development of sharing economy services in particular cities of the world, however synthesis is usually missing. The scientific output of presented research is then rather not presenting new facts about sharing economy services developed in cities, but generalisation and comparison of the situations and solutions observed in different places.

The text is organised as follows. In the beginning, the phenomenon of SE is described and interpreted with special focus on its positive and negative impacts, as well as a gap in scientific knowledge. Later, several cases of cities taking different approaches to different services offered within the scheme of SE are presented. As contemporary literature concentrates mainly on European and North American cities, similar spatial limit was adopted in the paper. Finally, synthesis of implemented approaches is offered as conclusions to the paper.

\section{THE NOTION OF SHARING ECONOMY}

Sharing economy (SE), also referred to as collaborative consumption (CC), peer-to-peer economy (P2P) and collaborative economy (CE), represents one of the most important current megatrends that has impact also on the development of contemporary tourism. As profit-based online platforms for the peer-to-peer sharing of consumer goods and services came into being, new ways for end-users to generate income from their possessions were provided. For example, in the case of accommodation services, SE platforms enable a multitude of property owners to rent second homes or even individual rooms to tourists, economically exploiting investments which were not initially intended to have a productive purpose (Moreno-Izquierdo et al., 2019). The growth of 
commercial internet platforms for P2P sharing such as Uber, Airbnb, Lyft, Housetrip or HomeAway has switched the way people travel and is of great importance and a threat to the traditional tourism industry (Heo, 2016). More and more tourist needs are satisfied within this particular formula (Paulauskaite et al., 2017). There are both strictly tourist needs (such as: transport, accommodation, food, sightseeing, etc.) and the complementary ones (e.g. taking care of the house left behind as a result of taking the trip, looking after the family members or pets left behind, etc.) among them (Kim, Fesenmaier, 2017). A relatively rapid increase in SE in tourism is forecast predominantly in terms of accommodation in private houses and renting private cars. PWC estimates that in Europe collaborative economy, peer-to-peer accommodation is the largest sector of the collaborative economy with an estimated total transaction value of $€ 15.1$ million in 2015 (Dredge et al., 2016).

SE should be interpreted based on two aspects, i.e. from the perspective of its goal and its scale. The former describes SE as an activity oriented towards reducing operating costs of the previously owned resources in a small scale (e.g. a person reports unused rooms in an apartment in which he/she lives), which is often carried out in an irregular, occasional manner, based on collaborative usage. SE defined in the above way is suggested to be referred to as a classical one. The latter is oriented towards generating profit, which is carried out in a larger scale (e.g. people purchase several apartments in order to offer them on the Airbnb platform). It is often linked with increasing service providers' resources in order to generate larger revenues, regular business activities where its negative economic, social and natural impacts can be easily noticed. It can be referred to as commercialised collaborative consumption. Surely, one of the factors that influence the balance of positive and negative effects is a scale of the SE development and huge business involvement, but the interpretation that small initial stage of SE development is sustainable, while the business-oriented, later stages are not, would be far too simplistic. However, Martin (2016) suggests that if the SE continues along this current pathway of corporate co-option, it is highly unlikely to drive a transition to sustainability. After development of companies like Airbnb, Uber and other companies from small startups to huge global companies, SE in tourism is nowadays mainly just a business. Geron (2013) indicates that the role of P2P sharing in rising personal incomes is vanishing and it is being transformed into a disruptive economic force.

Tourism remains one of the most important areas of development of SE (Varsanis et al., 2019). Accommodation and transportation platforms like Airbnb and Uber are among the most often researched issues and the biggest entities that grew up by offering direct combination of customers with suppliers in the SE. Even though SE in tourism is a very big and diverse phenomenon, most of the research and press releases are connected with two biggest platforms that enhance peer-to-peer relations, i.e. Airbnb in the hospitality sector and Uber in the passenger transportation. The size of their operations and the scale of their influence, as well as legal controversies make them very interesting topic of scientific debate, although they cannot be perceived as typical to the whole SE processes.

Fast development of the SE can be seen in big cities, where the new business model finds many supporters and followers. This trend is in line with the growing popularity of big cities as tourism destinations (Namberger et al., 2019). Since the impact of development of the $\mathrm{SE}$ in tourism is multidimensional and ambiguous with its positive or negative effect, it is necessary for the cities' authorities to be engaged in the process of 
its development to understand properly the scale and the direction of the development of the SE in a particular city as well as its impact, and to manage that development and to adopt the applicable regulations (Jaremen, Nawrocka, Żemła, 2020). However, usually it is difficult and not desired by the local authorities to manage development of the SE in tourism solely, on the contrary, that policy is often a part of the wider local attitude to development of collaborative consumption activities in different fields. The task is complicated as the data base of good examples and tools that might be utilised is dispersed and not very extensive. Very rapid development of this phenomenon caused that the theory does not catch up with the pace of changes. That is why we often derive the contemporary knowledge about solutions implemented in particular cities not only from scientific papers and books but also from the reports made by business consultancy agencies for the city decision-makers.

Codagnone (2017) states that conceptual ambiguity and rhetoric surround the sharing economy and, in the midst of value disputes and lack of evidence, policy and regulatory decisions are taken "in the dark" often under the influence only of some interest groups; in many cases it seems that politicians and policy makers have abdicated their role and are mute while courts and judges pronounce their judgements on whether Uber drivers are contractors or employees and on other matters.

\section{REGULATIONS, SOLUTIONS AND ATTITUDES TOWARDS THE SHARING ECONOMY TAKEN IN DIFFERENT CITIES}

Development of SE in tourism can be observed in almost all cities in the world, however due to local conditions and differences in local policy this development might follow different paths and create different externalities (Jaremen, Nawrocka, Żemła, 2020). Additionally different measures and attitudes of local stakeholders are to be met. As a result, especially in several European and North American cities, the scale of SE development and its impact is especially significant. This impact is also the best documented.

The cities selected for presentations below were chosen following several criteria. The most important was the availability of data. However this criterion cannot be perceived as the convenience factor only. The existence of numerous industry reports and scientific research suggests that the SE is treated as an important factor of local development by stakeholders and its impact is significant. Another criterion taken into consideration when selecting cities was the diversity of cases. Cities from both Europe and North America were included. Additionally, problems and positive effects created by SE development in particular cities are well differentiated and connected with different areas of local development.

\section{Amsterdam}

Many cities are welcoming new sharing economy business models although they quickly and sometimes aggressively immerse into the local economy and despite the regulatory barriers. With their diverse approaches, authorities of particular cities look for maximizing potential benefits and minimizing problems caused by the development of SE. Those benefits and problems are defined differently in different places. For example, after launching its Amsterdam Sharing City campaign in 2014, Amsterdam officially became Europe's first named sharing city (Dredge, Gyimóthy, 2015; Onente, Pleșea, Budz, 
2017). Böcker and Meelen (2017) named Amsterdam as a front-runner in the sharing economy due to the facts that local politicians and stakeholders promote initiatives in the sharing economy locally, nationally and internationally and it was the world's first municipality to develop regulations around Airbnb. It is worth noticing that Cheng (2016) described that regulations as "Airbnb friendly legislation". Amsterdam Sharing City label was launched by shareNL, which is a common initiative being a network of 'ambassadors', linking a variety of stakeholders, from corporates to startups, from community centres to public libraries, and from knowledge institutions to the city municipality (Probst et al., 2017). The idea of sharing is also strongly supported by citizens of the city (Action plan..., 2016). Amsterdam's approach can be illustrated by the statement: "to allow sufficient scope for innovation, renewal and entrepreneurial capacity, while at the same time adequately protecting public interests" (Dredge et al., 2016: 22). This means encouraging activities in the SE that will benefit from innovation, social inclusiveness, entrepreneurship and sustainability. Since digital platforms and the SE are perceived as a source of innovation and sustainability, the government wants to stimulate the developments within a flexible legal framework. However, development of SE activities within accommodation business not only may bring additional value but also creates significant problems in local entrepreneurship and legal regulation of innovation systems for those activities was necessary. The difficult task of this regulation was to make a distinction between residents' freedom in renting a room in their home and renting it for a short period while they are on holiday. To achieve this goal, permit and licensing requirements were established for properties owners. Restrictions on the intensity and level of commercialisation of tourist use (e.g. quotas and caps on licenses, presence of owner or tenant, length of stay) were also introduced (Dredge et al., 2016). All those actions helped to protect subsidized and social housing.

Approach of local authorities in Amsterdam to SE development seems to be wider than in other cities presented below. Usually, sharing economy is perceived as mainly accommodation services and public transportation services and sometimes, additionally, new technology-based, small scale and start-ups companies that offer niche services. Consequently, authorities in those cities are searching for solutions for proper development of particular sectors of SE separately. In Amsterdam, they are regarding SE as a whole and consider potential benefits and threats for both local economy and society globally. According to shareNL, the SE is opening up a wealth of opportunities and benefits for the city of Amsterdam, i.e. in terms of social cohesion, sustainability and savings (Probst et al., 2017). Those benefits are pointed as: (1) better access to services and products; (2) enhancement of social cohesion and inclusiveness; (3) sharing scarce resources more effectively and sustainably; (4) economic benefits and savings; (5) rethinking the role of a citizen; (6) improving efficiency of space and mobility; (7) development of creative industries and boosting innovation (Probst et al., 2017). This list may illustrate well how wide the range of positive effects is expected by Amsterdam authorities by developing the SE.

\section{Barcelona}

Very similar attitude, which means supporting innovative SE activities and regulating SE accommodation sector to defend the city against negative consequences, can be found in the actions and plans by local and regional governments of Barcelona. However, 
specific features and the pace of increase, as well as the level of tourism traffic in the city made authorities pay much more attention to dealing with sharing apartments activities than it was in Amsterdam. Barcelona was among the first cities in the world where the problem of overtourism was noticed as one of the major problems with famous protests of local residents against further tourism development (Goodwin, 2017). Additionally, economic crisis in Spain, which took place a few years ago and was strictly connected with speculative bubble on the real estate market, which was hit severely at that time, is an important background factor to the situation of the sharing apartments sector (de Weerdt, Garcia, 2016). According to Sans and Quaglieri (2016), the number of beds offered through Airbnb is around 30,000, which is equal to almost half of the hotel sector in the city. Finding new ways of sharing the city and its success seems to be the priority for the city authorities rather than selling the city, or re-making it for tourists. Barcelona has attempted to achieve this through changes in the civil codes and in the regulations for tourist facilities and the re-visioning of 'tourists' as 'temporary citizens', thereby seeking to shift the tourists from a pure consumer into a prosumer of culture (Richards, Marques, 2018). In this context, very strict regulations of short-term apartment rentals are not a surprise. All 'homes for tourist use' require a permit and shall be recorded in the Tourism Register of Catalonia (Dredge et al., 2016). Additionally, the registration number must be included in any advertising materials. Providers of apartments are obliged to pay income taxes and VAT derived from rental activity. Licensing requirements are not a dead regulation as they are actively enforced by the local government. At the same time, the Commons Start-up Support Programme La Comunificadora was introduced to support entrepreneurs in the collaborative economy. The city made a call for new initiatives; the thirty selected initiatives are provided with mentorship, legal advice, and match funding (van den Eijnden, 2017). The more commons-based initiatives are prioritized.

\section{Berlin}

The threat of uncontrolled development of short-term rental of real estates in SE platforms like Airbnb was noticed also in Berlin. Schäfer and Braun (2016) provide an evidence that over 5000 residential flats were being misused by Airbnb, which is $0.3 \%$ of the total housing stock in Berlin, and that many providers of entire flats have more than one offer simultaneously. Moreover, cited authors proves that Airbnb market is mainly located centrally and that only a few neighbourhoods have large Airbnb markets. However, local, historical conditions, made local authorities concentrate on the security of local real estate market. After the unification of Germany, Berlin, the capital city of the former Democratic Republic of Germany (the eastern, communist German country) faced a huge problem in achieving the level of development required for the capital city of the rich and modern Western-European country. The shortage of apartments and houses that fulfil these requirements were among the biggest problems. Several years after the unification, apart from the huge spending on the modernization of the eastern part of the country and in particular of Berlin, the problem has been still unsolved in the first two decades of the 21st century. Because of high profitability of the short-term rental, many attractive properties were moved from local housing market onto tourism market and thus they even increased the existing problems with shortages on the real estate market. Shortages on the supply side of the market also influenced prices of both 
the short-term and the long-term rentals which additionally increased accessibilities and affordability problems for the citizens. So, the concern of the local authorities was not strictly as much about fair competition, taxation and citizens' quality of life, as it was in the case of Barcelona presented above, but just security and stabilisation of local housing market. SE accommodation in Berlin is nowadays seen as a major factor stimulating the existing shortage of residential housing and problems with housing affordability. The only thing under any regulations is the way of using the housing and it does not affect business activity. Since changes of use for housing are banned (Change of Use Act), forms of housing that are permitted are simply set out, i.e. it sets out how owners and tenants are allowed to deal with housing (Dredge et al., 2016). The new law does not contain any regulatory elements that are specifically targeted at the tourism sector, at the SE. Banning changes of use for housing is intended to ensure that housing is used exclusively for permanent residence. Any other kind of use, for example commercial use, while a property is left vacant, demolishing housing, or renting out housing as a holiday apartment, is only permitted with a special permit from the local authority and active enforcement of licensing requirements with fines up to 100,000 EUR might be levied (Dredge et al., 2016). In this approach, so long as the dwelling remains a permanent residence, it is legal to rent out a room where the owner is present.

\section{Paris}

The aims and regulations introduced by Paris city authorities are very much similar to those presented above from Berlin. The ALUR (Loi pour l'accès au logement et un urbanisme rénové) Law was introduced in 2014 in order to introduce regulations for renting and establishing rent control (Wong, Goldblum, 2016). The stated aim of the ALUR Law is to act against failures in the housing market, to protect homeowners and tenants, and to promote the increasing housing supply (Dredge et al., 2016). The law was developed in part in order to introduce regulations for housing supply and affordability issues and to revitalise the real estate sector by introducing regulations for the conditions under which accommodation is rented. By prescribing conditions for rental agreements including time span of leases, the mechanism for regulating shortterm tourist accommodation in the SE is also provided. ALUR Law requires that residential property should be rented for a minimum of one year. If it is rented for a lesser period, it is a commercial operation and it requires a permit. If a property is turned into a commercial rental, the law requires the owner to compensate it by acquiring a commercial property and converting it to residential use (transfer to be approved by the city). Property owners who rent out their properties (secondary residences) must apply for permission under the tourism code (Code du tourisme). Fines may be levied for non-compliance (Dredge et al., 2016).

\section{Other examples of European cities}

An extremely negative influence of the SE accommodation business on the housing market is experienced in particular in the biggest cities which at the same time are the most popular tourism destinations like Paris, Berlin or Barcelona. However in other cities, like Krakow, even the scale of the development of Airbnb-like services is comparative to the one observed in Barcelona and Amsterdam (Borejza, 2020), the economic 
benefits derived from the development of tourism make local authorities showing some support for their further development. In the current tourism development plan (Polityka zrównoważonej turystyki Krakowa na lata 2021-2028), local authorities search for opportunities for catering bigger number of tourists also thanks to further development of SE. The most important limitation here is the requirement of strict control over following legal conditions. However, this is in strong contradiction with numerous symptoms of overtourism and anti-tourism attitudes observed in the city (Kruczek, Szromek, 2020; Plichta, 2019; Walas et al., 2018; Walas, 2019).

Similar problems can also be experienced in other cities, but often they are not perceived as a major threat while the scale of tourism is smaller and the number of real estates used for short-term tourism rental is lower and is does not influence local real estate market that much. In these cases, local authorities do not pay too much attention to regulations of the short-term properties rental and, more generally, accommodation services. Instead, when considering the SE development, they perceive this phenomenon rather as an opportunity to enhance their smart city strategies and to support entrepreneurship and innovativeness among the local citizens. Ghent, Antwerp or Bremen might be examples of these cities. In Antwerp, within the frames of Stadslab2050 vision, the SE is perceived as fitting well with the goals of Smart City Strategy, since new digital applications are also an important aspect of the SE concept (van Eijnden, 2017). The city supports technical start-ups in their ecosystem for digital innovations. This includes financial support, space, individual advice and matchmaking for technological start-ups and creative entrepreneurs in collaboration with the private sector. The SE has the potential to play a role within the Smart City Strategy, but the topic is to be addressed and specified in details in the nearest future.

Another important issue addressed by city authorities is improvement of local transportation system by implementation of sharing economy solutions. Ghent Councillor for Transport announced the Ghent Car-sharing Action Plan in October 2014. This plan sets the goal to increase the amount of car-sharers from 4,000 to 20,000 by 2020 (van Eijnden, 2017). The city aims to increase the number of car-sharing stations, to reduce the city car fleet and to integrate car-sharing, as well as bike sharing (Bauwens, Onzia, 2017), into new city developments. Similar attitude might be found in Bremen. Bremen is a pioneer city when it comes to car-sharing. In the 1990s, the first car-sharing initiatives have already started, initially as an answer to the needs of a small local groups of people (van Eijnden, 2017). A few years later, the city included car-sharing in the public transport pass, the so-called Bremer Karte. Contemporary way of development of car-sharing is building car-sharing stations close to bus and train stations and with an integrated bicycle parking to allow for easy switching between various transport modes and to enable the use of trams, buses and car-share within the city, at a low price (Calvert, Chatterjee, 2016). The City of Bremen's Sustainable Urban Mobility Plans (SUMP) integrates car sharing as a strategic element to reduce car ownership. The 2009 Car Sharing Action Plan set a target of 20,000 car sharing users by 2020 and the replacement of about 6,000 private cars through the service of car sharing. That Mobility Plan gains a lot o interest and esteem around Europe and received numerous awards (the 2014 CIVITAS Award and the 2015 SUMP Award) (Glotz-Richter, 2016). Car-sharing services stand also as an important part of the local transport development strategy in Copenhagen (Gössling, 2013), but in Copenhagen, car sharing supports perfectly developed bike-sharing system. Copenhagen is a self-declared "City of cyclists" or 
"world's best city for bicycling" as more than one third of its population use bikes everyday to get to and from work and education destinations (McLaren, Agyeman, 2015). It was also the first city in the world to introduce free bike-sharing stations (Gössling, 2013).

\section{EXAMPLES OF AMERICAN CITIES}

North American city governments are usually characterised by more entrepreneurial approach to governance and are searching for development models to satisfy citizens' needs. Indianapolis has approached the SE through what they have termed the "big tent" idea which welcomes any business that might have a positive impact on the city and its residents to pilot their product. Indianapolis continuously seeks ways to make its downtown vibrant and friendly and attract more traffic to the city. Contrary to many European cities presented above, extensive development of services of companies like Uber or Lyft is warmly welcomed here. It was noticed here that the presence of those companies has greatly improved transportation connections for both residents and visitors (Hirshon et al., 2015). Similarly open attitude can be seen in Dallas. According to the attitude of local authorities, the development of publicly desired services of SE platform is inevitable and the authorities should concentrate on the proper regulations instead of attempting to eliminate them from the market and protecting the traditional business model companies. The authorities in both these cities, i.e. Dallas and Indianapolis, emphasized that it is important to allow the market to decide whether SE services should be accommodated; they both went on to note that natural competition will decide which platforms will operate successfully in each city. The desire to be progressive is part of the fact that the constant evolution of new, innovative companies must be in progress in a city and it must accept some uncertainty in this process (Hirshon et al., 2015).

However, also in North American cities, authorities are aware of threats posed by rapid development of SE services in tourism. These are, among other things, consequences of Airbnb and similar platforms and their impact on the housing market in the New York City. According to the Report (BJH Advisors, 2016), switching from the long term rental on housing market into the short term tourism rental brings the property owner a significantly higher revenue. The same report indicates extremely close correlation (0.93) between Airbnb listings and median asking price for residential rental units. So close correlation suggests that the number of Impact Listings and asking prices are both increasing over time at a similar rate. To set a limit to that negative impact, the authorities introduced The New York State Multiple Dwelling Law that prohibits occupation of units within residential buildings that consist of three or more units for less than 30 days, unless a permanent resident is present during the rental period. Thus, short-term rentals that allow the tenant to book an Entire Apartment/Home in multiple dwellings violate the Multiple Dwelling Law. However, the authors of the Report found that in 2015 in New York City more than 55\% of Airbnb listings allowed to book an Entire Apartment/Home, which may suggest that at least part of them may violate the law (BJH Advisors, 2016). Even more sceptic are Wegmann and Jiao (2017). According to their research $72 \%$, of the more than 35,000 unique units used for urban vacation rentals violated New York City law. The example of the New York City illustrates that regulations for the development of SE business is a controversial issue not only because of problems with finding the proper and desired solution, but also the execution of that 
solution remains difficult and might be inefficient. Even more strict regulations might be found in few other Americans cities like Las Vegas, Orlando, Washington DC where short-term rental is prohibited as such for the cases when owners do not reside in the same house (Ključnikov, Krajčík, Vincúrová, 2018).

\section{DISCUSSION AND CONCLUSIONS}

The research results presented indicate that the authorities of particular cities adopt different attitudes towards the rapidly growing SE segment in tourism. This is because $\mathrm{SE}$ is often perceived in broader view as a global phenomenon that includes processes that are perceived positively and negatively. Cities such as San Francisco, Paris, London and Singapore, have opened doors for political reforms that could facilitate the collaborative economy (Onete, Pleşea, Budz, 2018). Therefore, the observed areas of regulations in particular cities, as well as the ways they are introduced are diversified. Definitely, the greatest concern of the city authorities is fast and unrestrained development of services through global platforms in the accommodation and passenger transport industry, and the powerful global leaders of these markets - Airbnb and Uber have become very important partners for local governments, but also difficult ones (Moreno-Gil, Coca-Stefaniak, 2020). As far as the development of rental of accommodation services through SE platforms is concerned, most of the negative consequences are the consequences of this development for the local real estate market and, consequently, this is where the local authorities attempt to introduce most of the regulations. In many cities, the phenomenon of replacing long-term rental of real estate for residential purposes by more profitable short-term rental for tourists can be seen. It also is the reason why the prices of real estate are increasing and limitations are set to the availability to the residents of renting or buying a house or flat. In order to prevent this, no-business-allowed zones in residential premises (e.g. in Berlin) are defined or an obligation to obtain a permit for renting residential premises is established (Barcelona, Paris), or restrictions that set limitations for this rental (New York, Paris) are imposed. Relatively less attention is paid by the local authorities of the cities researched to restraining the second important negative consequence of the rapid development of the accommodation offer available on SE platforms in individual cities. This consequence is the development of the gray economy and the unfair competition with traditional hotel industry businesses. In principle, all the regulations mentioned above assume that accommodation providers run their business in the official area of the economy, however, primarily in Barcelona, a very clear indication of the need to pay all the required tax charges is made. Apart from eliminating the gray economy, the authorities of the cities researched do not interfere in competition between the traditional hoteliers and accommodation services that are part of the SE model. However, Gurran and Phibbst (2017) state that local land use planning frameworks are still not equipped to regulate the new forms of visitor accommodations enabled by the Airbnb and similar platforms or the potential conflicts arising from increasing numbers of tourists. The same authors conclude further that local planners will need to revise zoning and residential development controls to distinguish between different forms of short-term accommodation listings enabled by Airbnb and to manage their differential impacts on neighbourhoods and permanent rental housing. 
In the cities researched, local authorities' approach the development of Uber platforms is also extremely differentiated. On the one hand, examples, especially with American cities, can be given where local authorities' approach to this phenomenon is positive, if not enthusiastic. On the other hand, in many cases of European cities, local authorities consider the development of public transport as a comprehensive system, with Uber, Lyft and other such platforms, but also companies that offer shortterm car-sharing as well as bicycles, as part of it. So, the goal is primarily to create the efficient transport solutions, while the regulations for individual components of this system slightly recedes into the background. The reasons for this are two facts. First of all, the change in Uber's attitude, which in order to improve its image, is more and more willing to cooperate with local authorities and to meet their legitimate expectations. Secondly, the regulations for this type of services in most countries is in progress or is discussed, mainly at the domestic level.

While the accommodation and passenger transport services with passenger cars in the SE model have been heavily commercialised with a significant share of the global Internet platforms, other sectors with the potential to develop a SE provide greater opportunities to implement the primary SE tasks and functions such as real sharing of goods, optimisation in using individual goods, and development of small entrepreneurship and innovativeness. This can also be seen in the attitude of the local authorities of many cities researched that are highly committed to developing these services, not only by reducing unnecessary regulations, but also through housing, training or even investment support.

The measures adopted in particular cities are often hard to evaluate as they require more time to prove they are effective (Brauckmann, 2017). Particular publications often do not present in-depth evaluations of how effective the described solution used in particular cities are. However, it is observable that actions taken by the local authorities tend to be reactive, rather than systematic, and concentrated only on solving isolated current problems (Jaremen, Nawrocka, Żemła, 2020). Additionally, the decision about the regulation characteristics is to be taken based on imperfect information (Pawlicz, 2019). It might be suggested that the development of the SE is to be treated in a way described by Hall $(1994,2011)$ as a third-order change (Jaremen, Nawrocka, Żemła, 2020), which means the shift in the whole policy paradigm (Greener, 2001; Hall, 2011). According to Hall (1994) first-order change involves incremental, routinised, satisfactory behaviour that leads to a change of the basic instruments of policy and the second-order change is a modification of the strategic behaviour of authorities. Second order change is therefore more strategic in form although officials and policy experts still remain relatively isolated from external political pressures (Hall, 2011). In the third-order change the new goal hierarchy is adopted by policymakers because the coherence of the existing policy paradigm has been undermined. This occurs if a failure in the perceived policy results in discrepancies or inconsistencies that cannot be explained within the existing paradigm (Greener, 2001). The contemporary SE development creates so different conditions for the functioning of cities that without paradigm shift and establishing a comprehensive attitude towards the problem, the policymakers may only react and minimize particular costs of the SE development. At that moment, there are no convincing examples of authorities that would take such an approach toward the externalities of the development of the SE. 


\section{References}

Action plan sharing economy. (2016). The city of Amsterdam. Amsterdam.

Bauwens, M., Onzia, Y. (2017). Commons Transition Plan for the City of Ghent. Retrieved from: https://blog.p2pfoundation.net/a-commons-transition-plan-for-the-city-of-ghent/2017/09/14 (Accessed on 16.10.2018).

BJH Advisors. (2016). Short Changing New York City. The impact of Airbnb on New York City's housing market. New York: BJH Advisors.

Borejza, T. (2020, 16 November). Kraków ma więcej Airbnb na mieszkańca niż Barcelona. „Potencjał nie osiagnął maksimum”. Retrieved from: https://krowoderska.pl/krakow-ma-wiecej-airbnb-na-mieszkanca-niz-barcelona-potencjal-nie-osiagnal-maksimum/.

Brauckmann, S. (2017). City tourism and the sharing economy - potential effects of online peer-to-peer marketplaces on urban property markets. Journal of Tourism Futures, 3(2), 114126.

Böcker, L., Meelen, T. (2017). Sharing for people, planet or profit? Analysing motivations for intended sharing economy participation. Environmental Innovation and Societal Transitions, 23, 28-39.

Calvert, T., Chatterjee, K. (2016). The EVIDENCE project. Measure no. 18 - New models of car use. World Transport Policy and Practice, 22(1/2), 171-185.

Cheng, M. (2016). Sharing economy. A review and agenda for future research. International Journal of Hospitality Management, 57, 60-70.

Codagnone, C. (2017). Lobbying as rhetorical framing in the "sharing economy". A case study on the limits and crisis of the evidence based policy paradigm. DigiWorld Economic Journal, $108,15-44$.

De Weerdt, J., Garcia, M. (2016). Housing crisis. The Platform of Mortgage Victims (PAH) movement in Barcelona and innovations in governance. Journal of Housing and the Built Environment, 31(3), 471-493.

Dredge, D., Gyimóthy, S. (2015). The collaborative economy and tourism. Critical perspectives, questionable claims and silenced voices. Tourism Recreation Research, 40(3), 286-302.

Dredge, D., Gyimóthy, S., Birkbak, A., Elgaard Jensen, T., Madsen, A. (2016). The impact of regulatory approaches targeting collaborative economy in the tourism accommodation sector. Barcelona, Berlin, Amsterdam and Paris. Impact Paper, 9.

Geron, T. (2013). Airbnb and the Unstoppable Rise of Share Economy. Forbes, 191, 58-62.

Glotz-Richter, M. (2016). Reclaim street space! - exploit the European potential of car sharing. Transportation Research Procedia, 14, 1296-1304.

Goodwin, H. (2017). The challenge of overtourism. Responsible Tourism Partnership Working Paper, 4.

Gössling, S. (2013). Urban transport transitions. Copenhagen, city of cyclists. Journal of Transport Geography, 33, 196-206.

Greener, I. (2001). Social learning and macroeconomic policy in Britain. Journal of Public Policy, $21,133-152$.

Gurran, N., Phibbst, P. (2017). When tourists move in. How should urban planners respond to Airbnb? Journal of the American Planning Association, 83(1), 80-93.

Hall, C.M. (1994). Tourism and Politics. Policy, Power and Place. Chichester: John Wiley.

Hall, C.M. (2011). Policy learning and policy failure in sustainable tourism governance. From firstand second-order to third-order change? Journal of Sustainable Tourism, 19(4-5), 649-671.

Heo, C.Y. (2016). Sharing economy and prospects in tourism research. Annals of Tourism Research, $58,166-170$.

Hirshon, L., Jones, M., Levin, D., McCarthy, K., Morano, B., Simon, S. (2015). Cities, the sharing economy and what's next. New York: National League of Cities.

Jaremen, D.E., Nawrocka, E., Żemła, M. (2019). Collaborative consumption impact on tourism growth and sustainable city development. Hradec Economic Days, 9(1), 329-338.

Jaremen, D.E., Nawrocka, E., Żemła, M. (2020). Externalities of development of the sharing economy in tourism cities. International Journal of Tourism Cities, 6(1), 138-157.

Kim, J., Fesenmaier, D.R. (2017). Sharing tourism experiences. The posttrip experience. Journal of Travel Research, 56(1), 28-40. 
Ključnikov, A., Krajčík, V., Vincúrová, Z. (2018). International sharing economy. The case of AirBnB in the Czech Republic. Economics \& Sociology, 11(2), 126-137.

Kruczek, Z., Szromek, A.R. (2020). The Identification of Values in Business Models of Tourism Enterprises in the Context of the Phenomenon of Overtourism. Sustainability, 12(4), 1457.

Martin, C.J. (2016). The sharing economy. A pathway to sustainability or a nightmarish form of neoliberal capitalism? Ecological Economics, 121, 149-159.

McLaren, D., Agyeman, J. (2015). Sharing cities. A case for truly smart and sustainable cities. Cambridge, MA; London: The MIT Press.

Moreno-Gil, S., Coca-Stefaniak, J.A. (2020). Overtourism and the sharing economy - Tourism cities at a crossroads. International Journal of Tourism Cities, 6(1), 1-7.

Moreno-Izquierdo, L., Ramón-Rodríguez, A.B., Such-Devesa, M.J., Perles-Ribes, J.F. (2019). Tourist environment and online reputation as a generator of added value in the sharing economy. The case of Airbnb in urban and sun-and-beach holiday destinations. Journal of Destination Marketing \& Management, 11, 53-66.

Namberger, P., Jackisch, S., Schmude, J., Karl, M. (2019). Overcrowding, overtourism and local level disturbance. How much can Munich handle? Tourism Planning \& Development, 16(4), 452-472.

Onete, C.B., Pleşea, D., Budz, S. (2018). Sharing economy. Challenges and opportunities in tourism. Amfiteatru Economic, 20(12), 998-1015.

Paulauskaite, D., Powell, R., Coca-Stefaniak, J.A., Morrison, A.M. (2017). Living like a local. Authentic tourism experiences and the sharing economy. International Journal of Tourism Research, 19(6), 619-628.

Pawlicz, A. (2019). Pros and cons of sharing economy regulation. Implications for sustainable city logistics. Transportation Research Procedia, 39, 398-404.

Plichta, J. (2019). The co-management and stakeholders theory as a useful approach to manage the problem of overtourism in historical cities - illustrated with an example of Krakow. International Journal of Tourism Cities, 5(4), 685-699.

Probst, L., Pedersen, B., Lonkeu, O.K., Amato, F. (2017). Amsterdam's collaborative economy. Amsterdam: Digital Transformation Monitor.

Richards, G.W., Marques, L. (2018). Creating synergies between cultural policy and tourism for permanent and temporary citizens. Barcelona: Committee on Culture of UCLG.

Sans, A.A., Quaglieri, A. (2016). Unravelling Airbnb. Urban perspectives from Barcelona. In: A.P. Russo, G. Richards (eds.), Reinventing the local in tourism. Producing, consuming and negotiating place. Bristol; Buffalo; Toronto: Channel View Publications, 209-228.

Schäfer, P., Braun, N. (2016). Misuse through short-term rentals on the Berlin housing market. International Journal of Housing Markets and Analysis, 9(2), 287-311.

Van den Eijnden, L. (2017). Governing Sharing Cities. A Comparative Case Study of Nine European Cities. Utrecht: Utrecht University.

Varsanis, K., Belias, D., Papailias, S., Chondrogiannis, M., Rossidis, I., Mantas, C., Koustelios, A. (2019). The Sharing Economy and How It Affects the Conditions of Consumption and Competition in the Tourism Industry. The Case of Airbnb in Greece. In: A. Kavoura, E. Kefallonitis, A. Giovanis (eds.), Strategic Innovative Marketing and Tourism. Vol. 1. Cham: Springer, 85-92.

Walas, B. (2019). Turystyczny najem krótkoterminowy w ocenie interesariuszy lokalnych. Biuletyn Komitetu Przestrzennego Zagospodarowania Kraju PAN, 275, 49-62.

Walas, B., Kachniewska, M., Mikołajczyk, A., Zmyślony, P. (2018). Historical Cities 3.0. Residents and Visitors - In Search of Quality and Comfort. Krakow: Municipality of Krakow.

Wegmann, J., Jiao, J. (2017). Taming Airbnb. Toward guiding principles for local regulation of urban vacation rentals based on empirical results from five US cities. Land Use Policy, 494501.

Wong, T.C., Goldblum, C. (2016). Social housing in France. A permanent and multifaceted challenge for public policies. Land Use Policy, 54, 95-102.

The project is financed by the Ministry of Science and Higher Education in Poland under the programme "Regional Initiative of Excellence" 2019-2022 project number 015/RID/2018/19 total funding amount 10 721040,00 PLN 
Michał Żemła, PhD, associate professor, Pedagogical University of Krakow, Institute of Geography, Department of Tourism and Regional Studies. The author of numerous publications on destination's product marketing and competitiveness. The subject of his main interest is development of tourism in mountain areas with special regard to winter sports and hiking tourism.

ORCID: https://orcid.org/ 0000-0002-3521-8128

\section{Address:}

Pedagogical University of Krakow

Institute of Geography

Department of Tourism and Regional Studies

ul. Podchorążych 2

30-084 Kraków, Polska

e-mail:michal.zemla@up.krakow.pl

Daria Elżbieta Jaremen, PhD, assistant professor, Wroclaw University of Economics and Business. A research worker and an academic teacher in the Department of Tourism Economy Marketing and Management, also involved in business practice as a travel agent, an entrepreneur and the chairman and member of museum councils. Her research interests are focused on the issues of broadly approached tourism economy, including the economics and management of tourist enterprises, also covering sustainable tourism and tourist consumption, as well as its contemporary problems. The author of numerous publications on tourists behaviour, sharing economy, tourist enterprise management and marketing.

ORCID: https://orcid.org/ 0000-0001-8726-7573

\section{Address:}

Wroclaw University of Economics and Business

Faculty of Management

Department of Marketing and Management in Tourism Economy

ul. Nowowiejska 3

58-500 Jelenia Góra, Polska

e-mail: daria.jaremen@ue.wroc.pl

Elżbieta Nawrocka, PhD, associate professor, Wroclaw University of Economics and Business, Department of Tourism Economy Marketing and Management. The author of numerous publications on tourism destination image, marketing, competitiveness and sustainability development in tourism. The subject of her latest interest is the development of modern technology (social media, Industry 4.0) and sharing economy in tourism.

\section{ORCID: https://orcid.org/ 0000-0002-5049-4788}

\section{Address:}

Wroclaw University of Economics and Business

Faculty of Management

Department of Marketing and Management in Tourism Economy

ul. Nowowiejska 3

58-500 Jelenia Góra, Polska

e-mail: elzbieta.nawrocka@ue.wroc.pl 